$\overline{6} \sqrt{6}$ の部位に京セラ社製単結晶酸化アルミナインプラ ント“バイオセラム” 3 S IS の長径を短く改造したもの を植立した，インプラント植立後， 7 日目に上部構造物 を装着し, 片側は実験側として全く清掃を行わず，他側 は清掃側として週 2 回の口腔清掃を行った.インプラン 卜植立後は, 雪坧の蓄積を促すため, 軟性 飼料觉与元 た。臨床的評価としては, 2 週間に 1 度, 口腔内写真, 雪垢付着量, 歯肉炎症指数, ペリオトロンによる歯肉淢 浸出液, probing depth, X線撮影を行った。今回の評 価の対象は, 植立後 1 力月 9 例, 3 力月 6 例, 6 力月 2 例である。

Plaque indexは，煩側面では，実験側，清掃側とも に高い值を示したが，舌側面では，実験側，清掃側とも に低い值であった. Gingival index は, 実験側煩側面 では高い值を示したが，舌側面では煩側面より低い值を 示した。また，実験側では，清掃側と比較して高い值を 示した。ペリオトロンによる蒾肉㩐浸出液測定值は, 実 験側煩側面では，清掃側と比較して有意に大きい値を示 したが，舌側面では，実験側と清掃側の間に有意な差は 認められなかった，X線学的には，植立後 3 カ月までは 実験側と清掃側との間に著明な差異は認められなかった が，植立後 6 力月では，実験側蒾槽頂部の骨吸収像がわ ずかに増加するものもみられた。

\section{6. コンポジットレジンへのタンパク質の吸着}

\section{○和田 正之・佐々木一彦・寺下 正道 長野三代太 （九歯大・ 1 保存）}

コンポジットレジン表面に扔けるプラーク形成は，2 次う蝕あるいは曾周疾患の誘因となり，またレジン自体 をも劣化させると考えられる。そこで，レジン表面の物 理化学的な性状を改善し，プラーク形成の抑制を行なえ ば，それらの問題の解決に有効であると思われる，歯質 へのタンパク質の選択的吸着に関してはいくらかの報告 がみられるが，修復材に対するものはほとんど知られて いない。

そてで演者らは，コンポジットレジン(Clearfil FII， Palfique, Microrest AP) に対する albumin および $\alpha$-globulin の吸着動態を， その吸着量の変化，pH お3 よびタンパク質濃度の影響という観点から調べた。

タンパク質の溶出傾向は, BSA では溶出量は最初緩 やかに増加し，最終の $500 \mathrm{mM}$ でかなりの增加をみた。
また， $\alpha$-globulin では，BSA より低濃度の $300 \mathrm{mM}$ で 大きな溶出量の増加をみた。両タンパク質ともかなりイ オン強度を上げないと溶出が進行しないと思われる。ま た，両タンパク質とも 3 種のコンポジットレジン間で, 各段階での溶出量にほとんど差はなかった。吸着量はど のレジンとも BSA に比べて $\alpha$-globulin の方が多く, 約 $2 \sim 3$ 倍であった。

$\mathrm{pH}$ の影響をみる実験では，両タンパク質とも，吸着 量が5.6から徐々減少し，7.4で最も吸着量が少なくな り，8.0では再び増加した。

タンパク質溶液の濃度による吸着量の変化では, 両夕 ンパク質とも低濃度でプラトーに達した，BSA および $\alpha$-globulin のコンポジットレジンに対する吸着は $\mathrm{La}-$ ngumuir 型になるととがわかった。すなわち，その吸 着は単分子首で完了するととが考えられ，さらにその吸 着形態は, end-on 型であると予想される。

\section{7. 㐘科用陶材の粒子の移動が色調に及ぼす影響}

\section{○劉嘉東・内田 康也}

(九䨑大 $\cdot 2$ 補緅)

歯科陶材の築盛時にコンデンスするととにより陶材粒 子がどのように移動するか，また，コンデンスの違いが 色調にどのような影響を与えるかという点を解明するた めに実験を行った。

陶材粒子の移動の観察には, 螢光塗料入りのエナメル 色陶材之螢光塗料を含まないデンティン色陶材を使用 した，まず，直径 $10 \mathrm{~mm}$ ，厚さ $0.4 \mathrm{~mm} の$ 下地金属片を Nichrombond で鋳造した。 また，分割テフロン型と 3 種類のスペーサ（オペーク用 $0.3 \mathrm{~mm}$, デンティンエナ メル用 $0.6 \mathrm{~mm}$ ) を作製した。このテフロン型とスペー サを用いて，試作コンデンサでコンデンスしながらオぺ 一ク陶材を築盛し，焼成した。その上にデンティン色陶 材を築盛し, デンティン色陶材の半分を除去後, 残りの 半分を焼成, 研磨し，乙の部分の上縁を計測の基準線と した.つぎに，最初に焼成したデンティンと同しさ高 (基準線と同高)になるまで，残りの半側にデンティン 色陶材を築盛し，その上に，螢光塗料を含んだエナメル 陶材を築盛，焼成したものを試験片とした。この試験片 を, 中央部, 中央から $1 \mathrm{~mm}$ ずつ離れた部分の合計 3 力 所で切断し，落射螢光顕微鏡を用いて，3 部位の基準線 からのエナメル螢光粒子の移動量を計測した。そ結 果，デンティン色陶材中へのエナメル螢光粒子の沈下量 
は 60〜 65 $\mu \mathrm{m}$ であり，測定した 3 部位間には，沈下量の 差は認められなかった。つぎに，オペーク陶材焼成後， デンティンを焼成し，その上にエナメルを築盛，焼成し た非積層群と，デンティンとエナメルを一度に築盛，㷬 成した積層群の 2 群に分けて，4 種類のコンデンス方法 の違い认よる表色の変化を測色色差コンピューターを用 いて測定した，その結果，どの焼成過程をとってみて も，コンデンスの違いによる表色の差は認められなかっ た.

今後は，コンデンス方法の違いが，缸材粒子の移動に ぞのように影響していくかという点について検討してい くつもりである.

\section{8. 永久歯の萌出直後のフッ素の取り込み及びフッ化物 歯面塗布後のフッ素保持に関する実験的研究}

○斎藤 敏昭・宮崎 秀夫・竹原 直道 (九歯大・韎）

永久苗萌出直後のエナメル質の変化を実際の口腔内で 経時的に観察することは技術的にも困難でその観察例も 少ない，そこで，今回，ヒトの完全埋伏歯を用い，乙れ を実際に上トの口腔内に保持することによって永久菌萌 出直後の状況を想定し，エナメル質表面のフッ素濃度及 びエナメル質の酸溶解性を32日間にわたって経時的に観 祭した。また，フッ化物歯面塗布が萌出直後の時期に行 われる場合を想定し，酸性フッ紊リン酸浴液 (APF) を 作用させた完全埋伏歯を口腔内に保持し，同じく32日閒 にわたって経時的に観察したので報告する.

実験に先だって，完全埋伏雬20雨について各歯面別に 酸溶解性とフッ素濃度を測定した。各蒾面とも，深層へ ゆくほどフッ素濃度は低下し，逆に酸溶解性は增加した が，各霜面間には有意差は認められなかった。

次に，フッ化物処理をしないままのエナメル質の経時 的観察では，時間とともにフッ素濃度は上昇し， $1 \mu \mathrm{m}$ の深さでは，32日後に，1\%の危険率で有意な上昇がみ られた。逆に，酸溶解性はしだいに低下した。

APF 処理群ではフッ素濃度は直後から急速に低下し， 2 日後には最低值を示したが，その後しだいに上昇し， 32 日後には $1 \mu \mathrm{m}$ の深さで $2000 \mathrm{ppm}$ まで上昇した。一 方, 酸溶解性は逆に上昇し, フッ素濃度が最低となる 2 日後にピークをむかえ，その後はりるやかに低下した。 これは，APF 作用直後にエナメル質表面に CaF とし て存在するフッ素の大部分が涶液の作用によって流出
し，その後は逆に，垂液中のフッ素がしだいに取り込ま れてゆくためと思われる。

以上の結果より，エナメル質の萌出後成熟は萌出後 1 力月の比較的短い期間においても明らかに認められ，ま た，萌出直後にフッ化物を作用させることにより，その 後の成熟に対して有利な結果をもたらすてとがわかる.

\section{9. 台湾青年の歯牙・歯周疾患に関する疫学的研究}

\section{○十刍 輝・宮崎 秀夫・北村 正明 松田 修司・竹原 直道}

(九蒾大 ・日衛)

宗 洋一郎 (九歯大 $\cdot 2$ 保存)

従来より，当教室では，ウ蝕や菌周疾患に関する疫学 調査を日本の内外に扑いて行っており，今回は1985年11 月に行なった調查より，台湾人青年の歯科突患の羅患状 態を報告した，被検者は，台湾台中书の医蕋薬系大学に 通学する，18〜24才の男 96名，女89名の計 185名で, DMF index, Oral hygiene index, PMA index, $に$ ついて検討を行ない，コントロールには本学学生およ び，付属歯科衛生学院生を用い，日本人と比較しながら 実態を明らかにした。

ウ蝕有病率は，台湾人，日本人とも $97 \%$ 以上と著しく 高率であった． DMF 歯数， $\mathrm{F}$ 歯数は，男女とも台湾人 が日本人より有意に少なく，D蒾数は，逆に多い傾向に あった。 OHI および CI は，台湾人が日本人ょり有意 に高く，DI は両国間に有意差は認められなかった。

PMA index は，A-I を除く全ての項目に扔いて，台 湾人が有意に高かった。

以上の成績を総括すると，台湾人が日本人よりウ蝕の 処置率は良くないものの，ウ蝕罹患性は低い結果が示さ れた．ての要因を考えると，台湾人は，日本人よりプラ ークコントロール (DI) 亿は大差ないてとから，学童期 からの食生活を初めとする環境要因の差に基づくものと 考えられる，また，歯周疾患の罹患性汇関しては，台湾 人の方が，日本人より悪い状態にあり，OHI の調查值， 特に CI の值が日本人より著しく高い事が直接の原因と なっていると考えられるが，台湾人の方が，歯石沈着の 起てり易い体質にあるのか，プラークコントロールや， 環境要因に起因するのかは，今後の検討に待ちたいと思 う. 